\title{
Biological Traits of Azotobacter Isolated from Marginal Soils and their Resistance to Tetracycline
}

\author{
Reginawanti Hindersah ${ }^{1, *}$, Priyanka Asmiran ${ }^{2}$, Etty Pratiwi ${ }^{3}$, Tualar Simarmata ${ }^{1}$ \\ ${ }^{1}$ Faculty of Agriculture Universitas Padjadjaran Jalan Raya Bandung-Sumedang Km. 21, Jatinangor, Sumedang 45363, Indonesia; \\ ${ }^{2}$ Graduated from Soil Science Master Program, Faculty of Agriculture, Universitas Padjadjaran, Indonesia; ${ }^{3}$ Soil Research Institute, Jalan \\ Tentara Pelajar 12, Bogor 16114, Indonesia;
}

Received: February 27, 2021; Revised: May 26, 2021; Accepted: July 19, 2021

\begin{abstract}
Multiple stress in soil due to abiotic and biotic stressor are the constraints of plant production. Human activity contributes to soil abiotic stress such as salt and heavy metal accumulation, and biotic stress cause by soil tetracycline contamination from manure. Nitrogen-fixing Azotobacter enable to increase plant growth and perform the biological activities in stressed soil. The objective of laboratory experiment was to determine the plant growth-related properties of some strain of Azotobacter isolated from saline and mercury-contaminated soil. Five isolates of Azotobacter were grown in liquid medium prior to nitrate, phytohormones, organic acids, and phosphatase analysis. All isolates were then tested for their susceptibility of tetracycline. Based on antibiotic resistance test, two Azotobacter isolates were further assessed for their ability to proliferate and produce exopolysaccharide in tetracycline-contaminated broth. The results verified that the five Azotobacter isolates produced different amounts of important metabolites for plant growth. Azotobacter c2a9 and K4 isolated from mercury- and salt-contaminated soil can respectively proliferate in the liquid culture with $5 \mathrm{mg} / \mathrm{L}-87.5 \mathrm{mg} / \mathrm{L}$ tetracycline. In the presence of $100 \mathrm{mg} / \mathrm{L}$ tetracycline, their growth was limited but they still produced low concentration of exopolysaccharides. This experiment suggested that Azotobacter has a potency to improve plant growth in the multiple-stressed soil.
\end{abstract}

Keywords: Azotobacter, Cell viability, Mercury contaminated soil, Metabolites, Saline soil, Tetracycline

\section{Introduction}

Soil is a natural reservoir of antibiotic since certain soil microbes produce antibiotic as defense mechanisms to other microbial attack (Massadeh and Mahmoud, 2019). Bacteria and fungi in soil are reported to produce antibiotic-like compounds and antibiotics such as streptomycin, and tetracycline (Al-Saraireh et al., 2015; Chandra and Kumar, 2017). Handling the livestock's health with antibiotics and then adding their manure in agricultural soil can increase antibiotic content in soil (Cycoń et al., 2019). Soil antibiotic residue due to frequent use of manure in agriculture can cause biotic stress to soil microbes as well as plants.

Tetracyclines are a broad-spectrum antibiotic frequently used for veterinary practice due to their low cost (Granados-Chinchilla and Rodríguez, 2017). A total of 93 countries used tetracycline commonly for animals compared to another antimicrobial agents (OIE, 2020). The concentrations of tetracycline in pig and poultry manure were ranging from a few of $\mathrm{mg} / \mathrm{kg}$ to hundreds of $\mathrm{mg} / \mathrm{kg}$ (Ghirardini et al. 2020). Tetracyclines contamination in soil may induce soil microbial resistant (Wepking et al., 2017). The presence of tetracycline in soil is reported to affect the seedling appearance and metabolic activities due to chlorophyll degradation (Margas et al., 2019). Despite the risk of antibiotic increment in soil, manure amendments are always recommended to increase the soil health and crop production of marginal soil in tropics.

Abiotic and biotic stress in soil reduces plant productivity and limits soil microbial activity in maintaining soil nutrient cycles. Soil stress induced by escalated concentration of metallic ions, salts and antibiotics disturbs microbial metabolism and hence their proliferation and function. Nowadays, plant growth promoting rhizobacteria (PGPR) is progressively used as a biofertilizer in sustainable agriculture. The application of PGPR in marginal soils might decrease the ability of microbes to multiply and their function related to their biological characteristics. Introduction of multiple-stress resistance PGPR has a potency to overcome those issues.

The Azotobacter is well known PGPR widely used as biofertilizer for food crops production. The mechanisms by which Azotobacter induce plant growth and productivity are nitrogen $(\mathrm{N})$ fixation; phytohormones, organic acids and exopolysaccharides (EPS) production; and phosphate solubilizing. Inoculation of Azotobacter on important food crops are reported to increase $\mathrm{N}$ content in soil and plant growth (Kurrey et al., 2018; Hindersah et al., 2018; Mahato and Kafle, 2018; Suárez-Moreno et al., 2019).

Researchers reported the ability of Azotobacter to produce phytohormones Indole Acetic Acid (IAA) and Cytokinines (CKs) in liquid culture (Viscardi et al., 2016; Chobotarov et al., 2017; Hindersah et al., 2020). The CKs include zeatin, zeatin-riboside dan zeatin glucose also detected in nanoparticle solid-based inoculant (Chobotarov

\footnotetext{
* Corresponding author e-mail: reginawanti@unpad.ac.id.
} 
et al., 2017). The Azotobacter produces low-molecular weight organic acids for releasing phosphate ions from insoluble inorganic phosphor (Nosrati et al., 2014; ElBadry et al., 2016). However, the organic acid profile of Azotobacter has not been studied intensively.

The resistance of Azotobacter to mercury (Hg) and salinity has been documented. In the presence of 100 , 1,000 and 1,200 mg/L Cadmium (Cd), Chromium (Cr) and Nickel (Ni), A. chroococcum CAZ3 produced certain metabolites to avoid cell damage (Rizvi et al., 2019). At least four Azotobacter isolates withstand high temperatures and low $\mathrm{pH}$ (5-5.5) were able to grow on media containing $2 \%$ of $\mathrm{NaCl}$. Azotobacter S2 was resistant to $3.4 \% \mathrm{NaCl}$ but their growth was limited compared with the growth in the liquid media with 1.7\% (Hindersah et al., 2019).

Naturally, Azotobacter synthesize EPS on cell wall surface to protect nitrogenase from oxygen during nitrogen fixation. The EPS is a major mechanism by which bacteria adapt to the presence of cationic metal in their surroundings (Gupta and Diwan, 2017; Ventorino et al., 2019; Abd El-Ghany et al., 2020). The mechanisms of bacterial resistance to tetracycline (drug) may be native to the microorganisms (Reygaert, 2018). The EPS play a significant role in formation of biofilms which induce the tolerance to antibiotics and other external stress (Sharma et al., 2019) to benefit the agriculture in contaminated soil.

The inoculation of Azotobacter in marginal soils with multiple stress might reduce their viability, and their natural function related to plant growth promotion. So that introduced Azotobacter have to be resistance to soil stress. The objective of this laboratory experiment was to verify the plant growth-related properties of some strains of mercury- and saline-resistance Azotobacter; and their ability to proliferate and produce EPS in tetracyclinecontaminated broth.

\section{Materials and Methodes}

The research was conducted on February 2018 to July 2018 in Soil Biology Laboratory of Faculty of Agriculture, Universitas Padjadjaran, West Java, Indonesia. All Azotobacter isolates belong to Soil Biology Laboratory. The Azotobacter bd3a and Azotobacter c2a9 were isolated from mercury-contaminated gold tailing at Buru Regency, Maluku Province, Indonesia. The Azotobacter K4 and Azotobacter S2 were isolated from saline soil (EC 4 $\mathrm{ds} / \mathrm{cm}$ ) of paddy field in Karawang Regency, West Java, Indonesia. The control isolate, A. chroococcum BT1, was isolated from corn rhizosphere grown in uncontaminated Inceptisols soil. In vitro experiment consisted of four sub process (Figure 1). Five Azotobacter isolates were tested in the $1^{\text {st }}$ to $3^{\text {rd }}$ experiment.

The 4th experiment was carried out for two Azotobacter isolates selected from tetracycline resistance test. The $1^{\text {st }}-3^{\text {rd }}$ experiments were setup in completely block design with five replications. Analysis of variances $(p \leq 0.05)$ were performed to verify the effect of treatments on the parameters. The $4^{\text {th }}$ experiment was performed in triplicate without analysis of variance.

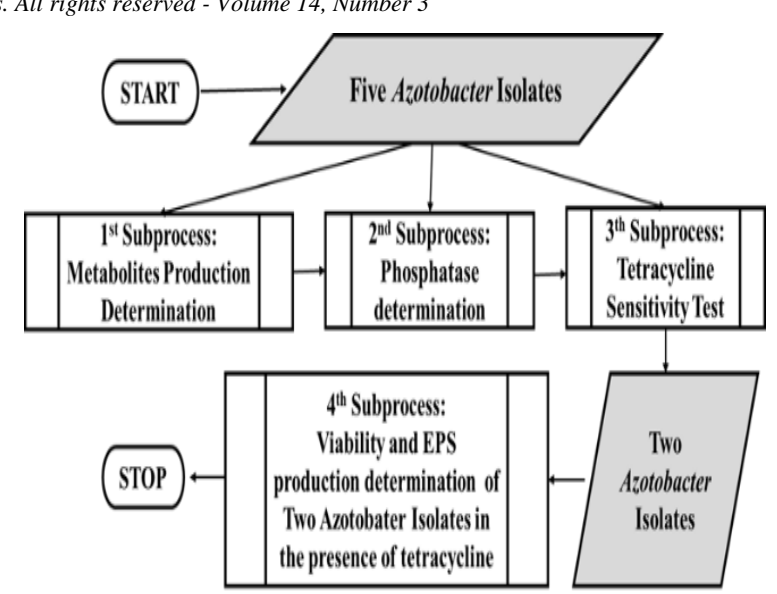

Figure 1. The process of laboratory experiment by using five isolates of N-fixing Azotobacter

\subsection{Determination of nitrate, phytohormones and organic acid production}

Each isolate was cultured in individual $100-\mathrm{mL}$ Erlenmeyer contained $50 \mathrm{~mL}$ of $\mathrm{N}$-free Asbhy's mannitol broth (Mannitol $20 \mathrm{~g}$, Dipotassium phosphate $0.2 \mathrm{~g}$, Magnesium sulfate $0.2 \mathrm{~g}$, Sodium chloride $0.2 \mathrm{~g}$, Potassium sulfate $0.1 \mathrm{~g}$, Calcium carbonate $5 \mathrm{~g}$ ). The culture then incubated for 72 hours at room temperature (24-27 ${ }^{0} \mathrm{C}$ ) on the 115 -rpm gyratory shaker.

At the end of incubation, Azotobacter liquid culture was centrifuged $10,000 \mathrm{rpm}$ at $4{ }^{0} \mathrm{C}$ for 10 minutes. Supernatants were collected for metabolites measurement. Nitrate quantification was carried out by using Kjeldahl Methods (AOAC, 2012; Sáez-Plaza et al., 2013). The presence of phytohormones IAA was determined by spectrophotometer at $510 \mathrm{~nm}$ after mixing $1 \mathrm{~mL}$ supernatant with $4 \mathrm{~mL}$ Salkowski reagents (Rahman et al., 2010). Supernatant was extracted with ethyl acetate (Hussain and Hasnain, 2009) prior to zeatin and kinetin quantification by using phase reserved High Performance Liquid Chromatograph at the wave lengths of $254 \mathrm{~nm}$ and $270 \mathrm{~nm}$, respectively.

Organic acids in the supernatant were analyzed by using phase reserved. Supernatant was filtered using 0.2 $\mu \mathrm{m}$ Whatman paper number 1 . The five organic acid standards and samples were injected into C18 column in isocratic conditions with $50 \mathrm{mM}$ Potassium dihydrogen phosphate as mobile phase. The measurement of organic acids was carried out at a wavelength of $210 \mathrm{~nm}$.

\subsection{Determination of Soluble phosphate and phosphatase activity}

Azotobacter isolates were grown in Pikovskaya broth (Yeast extract $0.5 \mathrm{~g}$, Dextrose $10 \mathrm{~g}$; Tricalcium phosphate $5.0 \mathrm{~g}$, Ammonium sulfate $0.5 \mathrm{~g}$, Sodium chloride $0.2 \mathrm{~g}$, Magnesium sulfate $0.1 \mathrm{~g}$, Mangan (II) sulfate $0.0001 \mathrm{~g}$, Ferrous sulfate $0.0001 \mathrm{~g}$ ) for 5 days at room temperature at shaking period of $115 \mathrm{rpm}$. The soluble phosphate was then determined by spectrophotometer at $880 \mathrm{~nm}$ (Behera et al., 2017). Azotobacter were grown in Pikovskaya broth for 3 days at room temperature prior to acid phosphatase activity measurement. The supernatant of bacterial culture was mixed with Disodium p-nitrophenyl phosphate (tetrahydrate). Phosphatase activity was defined based on the concentration of p-nitrophenol at $420 \mathrm{~nm}$ using UVVis spectrophotometer (Behera et al., 2017). 


\subsection{Tetracycline resistance test}

Tetracycline resistance assay for five Azotobacter isolates was performed with five antibiotic concentrations included 15, 20, 50, 100 and 1,000 $\mathrm{mg} / \mathrm{L}$ by using the disk diffusion susceptibility method (Jorgensen and Turnidge, 2015). A total of $1 \mathrm{~mL}$ liquid mother culture of Azotobacter was spread evenly on the surface of Ashby's plate agar and left 10 minutes at room temperature. Sterilized filter papers were impregnated with each antibiotic solution and placed on the surface of plate agar. The control treatment was sterilized water. All plates were incubated for 5 days at $30{ }^{0} \mathrm{C}$ prior to measure the inhibition zone around the antibiotic disk.

\subsection{Cell viability and exopolysaccharides production in the presence of tetracycline}

Based on the third experiment, plate agar of Azotobacter c2a9 and Azotobacter K4 showed smaller halo zone around paper disk dipped on $100 \mathrm{mg} / \mathrm{L}$ and $1,000 \mathrm{mg}$ tetracycline compared with another isolates. Both isolates were then used in the last experiment to test their viability and EPS production in the presence of 50 $\mathrm{mg} / \mathrm{L}-100 \mathrm{mg} / \mathrm{L}$ tetracycline. A total of $1 \%$ Azotobacter c2a9 and Azotobacter K4 pure liquid culture were inoculated separately into $50 \mathrm{~mL}$ Ashby broth contained 50, 62.5, 75, 87.5 and $100 \mathrm{mg} / \mathrm{L}$ tetracycline. All cultures were incubated on the gyratory shaker for $72 \mathrm{~h}$ at room temperature. Every experimental unit was carried out in triplicate. Asbhy's broth for the control treatments received no tetracycline. Population of Azotobacter was determined by serial dilution plate method ( $\mathrm{Pal}$ et al., 2017). Exopolysaccharides content in liquid culture were determined by gravimetric method after extracted the EPS from supernatant by cold acetone (Hindersah et al., 2017)

\subsection{Data analysis}

The data of $1^{\text {st, }} 2^{\text {nd }}$ and $3^{\text {rd }}$ trial were subjected to analysis of variance ( $\mathrm{F}$ test at $\mathrm{p} \leq 0.05$ ). If the sum square of treatments was significant for measured parameters than Duncan multiple range tests were performed at $\mathrm{p} \leq 0.05$.

\section{Results}

In Table 1 - Table 4, numbers in a column followed by the same letter were not significantly different based on Duncan's multiple range test $(\mathrm{P} \leq 0.05)$. Data depicted in Table 5 were not subjected to statistical analysis.

\subsection{Plant growth promoting related biological traits}

All isolates provided nitrate and produced IAA as well as zeatin, but they did not produce kinetin in Ashby's broth at $72 \mathrm{~h}$ after inoculation (Table 1). Duncan's test showed that nitrate content in the culture of all isolates was not significantly different. The IAA content in the bacterial supernatant significantly determined by the isolate but zeatin production by all isolates was not significantly different. In general, Azotobacter isolated from marginal soil demonstrated high IAA production compared with BT1 isolated from rhizosphere of maize grown in uncontaminated soil. The Azotobacter bd3a isolated from Hg-contaminated gold tailing produced highest IAA. Nonetheless, Azotobacter K4 isolated from saline soil produced lower IAA concentration than A. chroococcum BT1. All Azotobacter isolates released the same amount of zeatin.
Various composition of organic acids released by different isolates was shown after $72 \mathrm{~h}$ incubation (Table 2 ). The result showed that there was no significant difference in the concentration of maleic acid produced by the bacteria, but their oxalic and lactic acid production were different. Only Azotobacter bd3a and K4 excreted tartaric-acid into the broth. However, no acetic-acid was found in all culture. The Azotobacter BT1 (bacterial control) produced highest oxalic acid but lowest lactic acid compared with the Azotobacter isolated from contaminated sites. The acidity $(\mathrm{pH})$ of every broth culture were decreased from 7 before trial to about 6 (data were not presented).

Table 1. Nitrate and phytohormones content in N-free liquid culture of five different isolates of Azotobacter

\begin{tabular}{llll}
\hline Azotobacter isolates & $\begin{array}{l}\mathrm{NO}_{3}{ }^{-} \\
(\mathrm{mg} / \mathrm{L})\end{array}$ & $\begin{array}{l}\mathrm{IAA} \\
(\mathrm{mg} / \mathrm{L})\end{array}$ & $\begin{array}{l}\text { Zeatin } \\
(\mathrm{mg} / \mathrm{L})\end{array}$ \\
\hline BT1 & $123.4 \mathrm{a}$ & $9.0 \mathrm{a}$ & $0.151 \mathrm{a}$ \\
bd3a & $103.6 \mathrm{a}$ & $32.5 \mathrm{c}$ & $0.148 \mathrm{a}$ \\
c2a9 & $118.4 \mathrm{a}$ & $20.2 \mathrm{~b}$ & $0.143 \mathrm{a}$ \\
K4 & $88.8 \mathrm{a}$ & $6.5 \mathrm{a}$ & $0.156 \mathrm{a}$ \\
S2 & $108.6 \mathrm{a}$ & $23.4 \mathrm{~b}$ & $0.155 \mathrm{a}$ \\
\hline
\end{tabular}

Table 2. Organic acid production by five different isolates of Azotobacter in $\mathrm{N}$-free liquid culture

\begin{tabular}{lllll}
\hline \multirow{2}{*}{ Azotobacter isolates } & \multicolumn{3}{l}{ Organic acids $(\mathrm{mg} / \mathrm{L})$} \\
\cline { 2 - 5 } & Oxalic & Maleic & Lactic & Tartaric $^{\mathrm{a}}$ \\
\hline BT1 & $51.8 \mathrm{~b}$ & $0.16 \mathrm{a}$ & $6.6 \mathrm{a}$ & nd $^{\mathrm{b}}$ \\
bd3a & $14.6 \mathrm{a}$ & $0.15 \mathrm{a}$ & $11.7 \mathrm{~b}$ & 1.4 \\
c2a9 & $17.6 \mathrm{a}$ & $0.15 \mathrm{a}$ & $7.6 \mathrm{a}$ & nd \\
K4 & $15.9 \mathrm{a}$ & $0.15 \mathrm{a}$ & $10.5 \mathrm{~b}$ & 3.9 \\
S2 & $14.3 \mathrm{a}$ & $0.15 \mathrm{a}$ & $11.8 \mathrm{~b}$ & nd \\
\hline
\end{tabular}

${ }^{\mathrm{a}}$ Statistical analysis has not been performed on tartaric acid trait due to incomplete data, ${ }^{\mathrm{b}} \mathrm{nd}$, not detected

Available phosphate production and phosphatase activity depend on Azotobacter isolates (Table 3). Azotobacter c2a9 and Azotobacter S2 demonstrated the highest ability to produce soluble phosphate in liquid culture although it was not significantly different with the control (BT1). The higher phosphatase activity was shown by BT1 as well as c2a9 and S2 isolated from mercurycontaminated and saline soil, respectively.

Table 3. Soluble phosphate and phosphatase activity of Azotobacter isolates in Pikovskaya broth with calcium phosphate

\begin{tabular}{lll}
\hline $\begin{array}{l}\text { Azotobacter } \\
\text { isolates }\end{array}$ & $\begin{array}{l}\text { Soluble phosphate } \\
(\mathrm{mg} / \mathrm{L})\end{array}$ & $\begin{array}{l}\text { Phosphatase activity } \\
(\text { Unit/mL) }\end{array}$ \\
\hline BT1 & $0.24 \mathrm{c}$ & $0.62 \mathrm{c}$ \\
bd3a & $0.05 \mathrm{a}$ & $0.14 \mathrm{a}$ \\
c2a9 & $0.31 \mathrm{c}$ & $0.78 \mathrm{c}$ \\
K4 & $0.16 \mathrm{~b}$ & $0.41 \mathrm{~b}$ \\
S2 & $0.34 \mathrm{c}$ & $0.87 \mathrm{c}$ \\
\hline
\end{tabular}




\subsection{Azotobacter Resistance to Tetracycline}

Tetracycline assay showed that Azotobacter proliferation was repressed in the presence of higher concentration of tetracycline. Azotobacter isolate influenced the diameter of inhabition zone (Table 4). The absence of clear zones surrounding disk paper of $15 \mathrm{mg} / \mathrm{L}$ tetracycline indicated that all isolates were resistance to the tetracycline $\leq 15 \mathrm{mg} / \mathrm{L}$. The halo zone measurement demonstrated that Azotobacter BT1, bd3a, c2a9 and K4 enabled to proliferate in the presence of $20 \mathrm{mg} / \mathrm{L}$ and 50 $\mathrm{mg} / \mathrm{L}$ without being inhibited by tetracycline. The Azotobacter K4 was the most resistant to $100 \mathrm{mg} / \mathrm{L}$ tetracycline compared with other isolates from marginal soil. All isolates included BT1 (control) were susceptible to $1,000 \mathrm{mg} / \mathrm{L}$ tetracycline. Table 4 showed that Azotobacter c2a9 and K4 were more resistant to higher concentration of tetracycline than other isolates.

Table 4. Zone inhibition diameter around disk paper of different concentration of tetracycline on Azotobacter

\begin{tabular}{lllllll}
\hline Azotobacter isolates & \multicolumn{6}{c}{$\begin{array}{l}\text { Diameter of halo zone (cm) for each } \\
\text { tetrycline concentration (mg/L) }\end{array}$} \\
\cline { 2 - 7 } & $\mathrm{C}^{\mathrm{a}}$ & 15 & 20 & 50 & 100 & 1,000 \\
\hline BT1 & 0 & 0 & 0 & 0 & $0.00 \mathrm{a}$ & $2.76 \mathrm{~b}$ \\
bd3a & 0 & 0 & 0 & 0 & $0.67 \mathrm{ab}$ & $2.46 \mathrm{~b}$ \\
c2a9 & 0 & 0 & 0 & 0 & $0.56 \mathrm{ab}$ & $2.43 \mathrm{~b}$ \\
K4 & 0 & 0 & 0 & 0 & $0.26 \mathrm{a}$ & $1.73 \mathrm{a}$ \\
S2 & 0 & 0 & 0.56 & 0.86 & $1.16 \mathrm{~b}$ & $2.53 \mathrm{~b}$
\end{tabular}

${ }^{\mathrm{a} C o n t r o l ~ w i t h o u t ~ t e t r a c y c l i n e ~}$

\subsection{Cell viability and EPS production in the presence of tetracycline.}

Based on the third experiment, Azotobacter c2a9 and K4 (Fig 2) were more resistant to tetracycline. Nonetheless, a higher amount of tetracycline decreased the population of both isolates (Table 5). A clear reduction of c2a9 population was only shown in the presence of 87.5 and $100 \mathrm{mg} / \mathrm{L}$ of tetracycline; meanwhile, $50-100 \mathrm{mg} / \mathrm{L}$ tetracycline reduced the growth of $\mathrm{K} 4$. Table 5 showed that in the presence of tetracycline, the EPS content in liquid culture of c2a9 and K4 was lower than the control. A decreased amount of EPS of both isolates was related to the increase in tetracycline concentration.

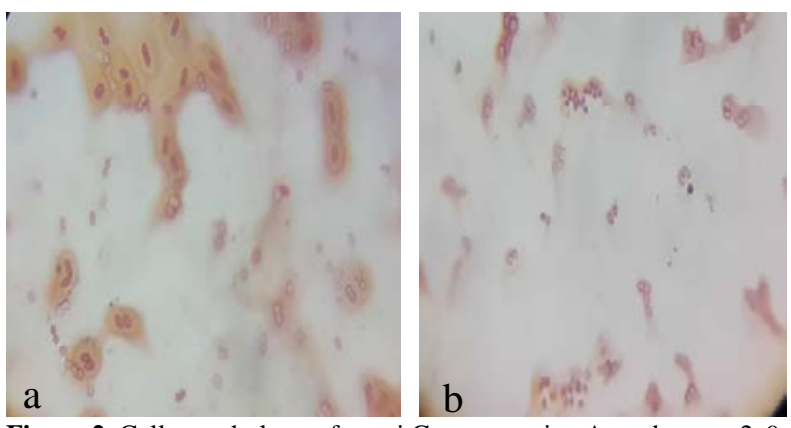

Figure 2. Cell morphology of cocci Gram-negative Azotobacter c2a9 (a) and K4 (b)
Table 5. Azotobacter count in N-free broth of c2a9 and K4 isolates contaminated with tetracycline.

\begin{tabular}{lllll}
\hline \multirow{2}{*}{$\begin{array}{l}\text { Tetracycline } \\
(\mathrm{mg} / \mathrm{L})\end{array}$} & \multicolumn{2}{l}{$\begin{array}{l}\text { Bacterial Population } \\
\left(\log _{10} \text { of cfu/mL) }\right.\end{array}$} & \multicolumn{2}{l}{ EPS $(\mathrm{mg} / \mathrm{L})$} \\
\cline { 2 - 5 } & $\mathrm{c} 2 \mathrm{a} 9$ & $\mathrm{~K} 4$ & 34.4 & 29.7 \\
\hline 0 & 5.48 & 5.48 & 27.1 & 25.7 \\
50 & 5.42 & 0.00 & 21.8 & 22.7 \\
62.5 & 5.23 & 1.00 & 17.3 & 20.7 \\
75 & 5.32 & 0.00 & 15.3 & 13.8 \\
87.5 & 2.78 & 0.00 & 9.07 & 5.72 \\
100 & $0.00^{\mathrm{a}}$ & $0.00^{\mathrm{a}}$ & $\mathrm{K} 4$ \\
\hline
\end{tabular}

Value is an average of three replications. ${ }^{\mathrm{a}}$ The colonies did not grow in plate agar with the culture from $10^{-2}$ dilution.

\section{Discussion}

The research confirmed that five Azotobacter isolates had a plant growth promoting related traits. The first experiment verified the presence of nitrate in cell-free supernatant extracted from $\mathrm{N}$-free liquid culture that proved the $\mathrm{N}$ fixation occurred in $\mathrm{N}$-free broth. The presence of IAA and Zeatin in liquid culture verified that synthesis of phytohormones by bacteria was taken place in diazotrophic condition. Phytohormones released by Azotobacter were depending on the isolates. The five isolates produced 9.0-32.5 IAA, the high IAA production were shown by isolates bd3a (32.5 mg/L) and S2 (23.4 $\mathrm{mg} / \mathrm{L})$.

The result demonstrated that IAA released by bd3a was more or less equal to IAA production by $A$. chroococcum 67B and 76, which were $28 \mathrm{mg} / \mathrm{L}$ and $34 \mathrm{mg} / \mathrm{L}$ respectively. The lower phytohormones production has been shown by A. chroococcum and $A$. vinelandii that only produce $0.52 \mathrm{mg} / \mathrm{L}$ and $0.82 \mathrm{mg} / \mathrm{L}$ of IAA (Hindersah et al., 2020). A significant amount of organic acids was detected in liquid culture of Azotobacter and hence reduced the culture $\mathrm{pH}$ from neutral to slightly neutral. Despite of the prominent role of organic acid to provide $\mathrm{P}$ for plant through P solubilizing, the research about organic acid production by Azotobacter is still limited. Moreover, all isolates demonstrated the ability to produce soluble $\mathrm{P}$ and phosphatase activity.

This experiment showed that all Azotobacter isolates produced soluble phosphate in Pikovskaya broth due to calcium phosphate solubilizing by organic acid. The phosphatase activity proved the ability of Azotobacter to carry out organic $\mathrm{P}$ mineralization catalyzed by phosphatase to produce available $\mathrm{P}$. The result agrees with the ability of some Azotobacter isolates that have phosphate solubilizing index ranging from 1.2 to 3.5 during 7-day incubation (Nosrati et al., 2014). More recent research demonstrated that $A$. vinelandii reach maximum phosphate solubilizing (25.3\%) in the presence of inorganic phosphate after 3 days by lowering the $\mathrm{pH}$ of Pikovskaya broth (El-Badry et al., 2016). The decrease of $\mathrm{pH}$ is caused by organic acid production by five Azotobacter isolates in our finding.

The growth of Azotobacter isolated from marginal soil was inhibited by higher concentration of tetracycline. The experiment showed that all Azotobacter isolates were susceptible to 100 and $1,000 \mathrm{mg} / \mathrm{L}$ tetracycline but the halo 
zone around Azotobacter c2a9 and K4 colonies was lower compared with other isolates. The Azotobacter K4 was more susceptible to tetracycline compared with c2a9. In the last experiment, Azotobacter c2a9 and K4 released $34.4 \mathrm{mg} / \mathrm{L}$ and $29.7 \mathrm{mg} / \mathrm{L}$ respectively in broth without tetracycline. Slight reduction of EPS production in broth with $62.5 \mathrm{mg} / \mathrm{L}$ and $50 \mathrm{mg} / \mathrm{L}$ verified their resistance to tetracycline. However, both isolates did not show resistance to high levels of tetracycline due to cell growth restriction. The increase of EPS by Azotobacter c2a9 and $\mathrm{K} 4$ in the presence of tetracycline might be related to bacterial protection against antibiotic by biofilm formation since EPS is a key element of biofilm extracellular matrix (Abebe, 2020).

Tetracycline is a broad-spectrum antibiotic; their targets are membrane system of Gram positive and negative bacteria. The resistance of Azotobacter to tetracycline is important for maintaining their proliferation and function include nitrogen fixation, as well as phytohormones, organic acids and EPS production. Some strains of $A$. chroococcum are resistant to $10 \mu \mathrm{g} / \mathrm{ml}$ of ampicillin, chloramphenicol, erythromycin, kanamycin, rifampicin, streptomycin, tetracycline and trimethoprim has been reported (Sindu et al., 1989).

Azotobacter might have a resilience for adapting to multitude environmental threats, including the presence of mercury, salt and tetracycline molecule. This intrinsic adaptation can maintain Azotobacter existence in plantrhizobacteria interaction that is very important for cycling the essential macronutrient nitrogen and promoting plant growth as well.

\section{Conclusion}

The Azotobacter isolated from marginal soil produced some important metabolites for improving plant growth. The available $\mathrm{N}$ (nitrate) was found in $\mathrm{N}$-free broth after Azotobacter inoculation that showed bacterial ability to fix nitrogen. Every Azotobcter isolates produce IAA and Zeatin as well. The bacteria produce organic acid which might be related to their properties in $\mathrm{P}$ solubilizing. Azotobacter c2a9 and K4 isolated from Hg-contaminated and saline soil respectively have the ability to proliferate in the presence of less than $87.5 \mathrm{mg} / \mathrm{L}$ tetracycline. They also produce EPS in liquid media with tetracycline up to 100 $\mathrm{mg} / \mathrm{L}$ although the EPS content is reduced significantly at higher concentration of tetracycline. The results verified that Azotobacter c2a9 and K4 isolated from abiotic stressed soil have the resistance to $87.5 \mathrm{mg} / \mathrm{L}$ tetracycline.

\section{Acknowledgements}

For the most part, this research was funded by Academic Leadership Grant of Universitas Padjadjaran. Isolation of Azotobacter from Hg-contaminated tailing and their resistance to $\mathrm{Hg}$ was funded by former Maluku Corner of Universitas Padjadjaran. The first author thanks the Head of Microbiology Laboratory at Soil Research Institute, Ministry of Agriculture in Bogor.

\section{References}

Abebe GM. 2020. The role of bacterial biofilm in antibiotic resistance and food contamination. Int $J$ Microbiol., 2020: 1705814.

Abd El-Ghany MF and Attia M. 2020. Effect of exopolysaccharide-producing bacteria and melatonin on faba bean production in saline and non-saline soil. Agronomy, 10(3): 316.

Al-Saraireh A, Al-Zereini WA and Tarawneh KA. 2015. Antimicrobial activity of secondary metabolites from a soil Bacillus sp. 7B1 Isolated from South Al-Karak, Jordan. Jordan J Biol Sci., 8(2):127 - 132.

AOAC. 2012. Official Methods of Analysis, 19th edition. Association of Official Analytical Chemist, Washington DC, USA.

Behera BC, Yadav H, Singh SK, Mishra RR, Sethi BK, Dutta SK and Thatoi HN. 2017. Phosphate solubilization and acid phosphatase activity of Serratia sp. isolated from mangrove soil of Mahanadi river delta, Odisha, India J Genet En Biotechnol., 15: 169-178.

Chandra N and Kumar S. 2017. Antibiotics producing soil microorganisms. In Hasmi et al. (Eds). Antibiotics and Antibiotics Resistance Genes in Soils: Monitoring, Toxicity, Risk Assessment and Management. Springer International Publishing AG, Switzerland, pp 1-18.

Chobotarov A, Volkogon M and VoytenkoL IK. 2017. Accumulation of phytohormones by soil bacteria azotobacter vinelandii and Bacillus subtilis under the influence of nanomaterials. J Microbiol Biotechnol food Sci., 7(3): 271-274.

Chun JA, Lim C, Kim D and Kim JS. 2018. Assessing impacts of climate change and sea-level rise on seawater intrusion in a coastal aquifer. Water, 10: 357.

Cycoń M, Mrozik A and Piotrowska-Seget Z. 2019. Antibiotics in the soil environment-degradation and their impact on microbial activity and diversity. Front Microbiol., 10: 338.

El-Badry MA, Elbarbary TA, Ibrahim IA and Abdel-Fatah YM. 2016. Azotobacter vinelandii Evaluation and optimization of Abu Tartur Egyptian phosphate ore dissolution. Saudi J Pathol Microbiol., 1(3): 80-93.

Ghirardini A, Grillini V and Verlicchi P. 2020. A review of the occurrence of selected micropollutants and microorganisms in di_erent raw and treated manure-environmental risk due to antibiotics after application to soil. Sc Total Environ., 707: 136118.

Granados-Chinchilla F and Rodríguez C. 2017. Tetracyclines in food and feeding stuffs: from regulation to analytical methods, bacterial resistance, and environmental and health implications. $J$ Anal Methods Chem., 2017: 315497.

Gupta P and Diwan B. 2017. Bacterial exopolysaccharide mediated heavy metal removal: a review on biosynthesis, mechanism and remediation strategies. Biotechnol Rep., 13: 5871.

Hindersah R, Mulyani O and Osok R. 2017. Proliferation and exopolysaccharide production of Azotobacter in the presence of mercury. Biodiv., 8(1): 21-26.

Hindersah R, Sulaksana DA and Herdiyantoro D. 2018. Perubahan kadar $\mathrm{N}$ tersedia dan populasi Azotobacter di rizosfer sorgum (Sorghum bicolor L.) yang ditanam di dua ordo tanah dengan inokulasi Azotobacter sp. Agrologia, 3(1): 10-17. In Indonesian, abstract in English. 
Hindersah R, Suryatmana P, Setiawati MR, Fitriatin BN, Nurbaity A and Simarmata T. 2019. Salinity resistance of Azotobacter isolated from saline soil in West Java. In Sayyed, RZ (Eds). Plant Growth Promoting Rhizobacteria (PGPR): Prospects for Sustainable Agriculture. Springer, Singapore, pp 323-334.

Hindersah R, Setiawati MR, Asmiran P and Fitriatin BN. 2020. Formulation of Bacillus and Azotobacter consortia in liquid cultures: preliminary research on microbes-coated urea. Int $J$ Agric Syst., 8(1): 1-10.

Hussain A and Hasnain S. 2009. Cytokinin production by some bacteria: its impact on cell division in cucumber cotyledons. African J Microbiol Res., 3(11): 704-712.

Jorgensen JH and Turnidge JD. 2015. Susceptibility test methods: dilution and disk diffusion methods. In Jorgensen JH et al. (Eds). Manual of Clinical Microbiology 11th Edition. American Society of Microbiology. pp 1253-1273.

Kurrey DK, Sharma R, Lahre MK and Kurrey RL. 2018. Effect of Azotobacter on physio-chemical characteristics of soil in onion field. The Pharma Innov J., 7(2): 108-113

Mahato S and Kafle A. 2018. Comparative study of Azotobacter with or without other fertilizers on growth and yield of wheat in Western hills of Nepal. Ann Agrar Sci., 16(3): 250-256.

Margas M, Piotrowicz-Cieślak AI, Michalczyk DJ and Głowacka K. 2019. A Strong Impact of Soil Tetracycline on Physiology and Biochemistry of Pea Seedlings. Scientifica, 2019: 3164706.

Massadeh MI and Mahmoud SM. 2019. Antibacterial activities of soil bacteria isolated from Hashemite University area in Jordan. Jordan J Biol Sci., 12(4): 503 - 511.

Nag NK, Dash B, Gupta SB, Khokher D and Soni R. 2018 Evaluation of stress tolerance of Azotobacter isolates. Biologija, 64(1): 82-93.

Nosrati R, Owlia P, Saderi H, Rasooli I and Ali Malboobi M. 2014. Phosphate solubilization characteristics of efficient nitrogen fixing soil Azotobacter strains. Iran J Microbiol., 6(4): 285-95.

OIE. 2020. OIE Annual Report on Antimicrobial Agents Intended for Use in Animals: Better Understanding of the Global Situation, fourth rep. World Organization for Animal Health (OIE), Paris.

Pal P, Khatun N and Banerjee SK. 2017. Potential screening of Azotobacter from soil. Int J Adv Res., 5(3):24-31.
Rahman A, Sitepu I R, Tang S-Y and Hashidoko Y. 2010. Salkowski's reagent test as a primary screening index for functionalities of rhizobacteria isolated from wild dipterocarp saplings growing naturally on medium-strongly acidic tropical peat soil. Biosci Biotechnol Biochem., 74(11): 2202-2208.

Reygaert WC. 2018. An overview of the antimicrobial resistance mechanisms of bacteria. AIMS Microbiol., 4(3): 482-501.

Rizvi A, Ahmed B, Zaidi A and Khan MS. 2019. Bioreduction of toxicity influenced by bioactive molecules secreted under metal stress by Azotobacter chroococcum. Ecotoxicol., 28(1): 302-22.

Sáez-Plaza P, Michałowski T, Navas MJ, Asuero AG and Wybraniec S. 2013. An overview of the Kjeldahl method of nitrogen determination. Part I. Early history, chemistry of the procedure, and titrimetric Finish. Crit Rev Anal Chem., 43(4): 178-223.

Sharma D, Misba L and Khan AU. 2019. Antibiotics versus biofilm: an emerging battleground in microbial communities. Antimicrob Resist Infect Control, 8: 76

Sindhu SS, Grover V, Narula N and Lakshminarayana K. 1989. Occurrence of multiple antibiotic resistance in Azotobacter chroococcum. Zentralbl Mikrobiol., 144(2): 97-101.

Suárez-Moreno ZR, Vinchira-Villarraga DM, Vergara-Morales DI, Castellanos L, Ramos FA, Guarnaccia C, Degrassi G, Venturi $\mathrm{V}$ and Moreno-Sarmiento N. 2019. Plant-growth promotion and biocontrol properties of three Streptomyces spp. isolates to control bacterial rice pathogens. Front Microbiol., 10: 290.

Ventorino V, Nicolaus B, Di Donato P, Pagliano G, Poli A, Robertiello A, Iavarone V and Pepe O. 2019. Bioprospecting of exopolysaccharide-producing bacteria from different natural ecosystems for biopolymer synthesis from vinasse. Chem Biol Technol Agric., 6: 18.

Viscardi S, Ventorino V, Duran P, Maggio A, De Pascale S, Mora ML and Pepe O. 2016. Assessment of plant growth promoting activities and abiotic stress tolerance of Azotobacter chroococcum strains for a potential use in sustainable agriculture. J Soil Sci plant Nutr., 16(3): 848-63.

Wepking C, Avera B, Badgley B, Barrett J E, Franklin J, Knowlton K F, Ray P P, Smitherman C and Strickland MS. 2017. Exposure to dairy manure leads to greater antibiotic resistance and increased mass-specific respiration in soil microbial communities. Proc Royal Soc B., 284(1851): 20162233. 